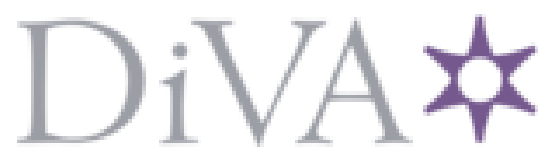

http://www.diva-portal.org

This is the published version of a paper published in Ecology.

Citation for the original published paper (version of record):

Sundqvist, M., Liu, Z., Giesler, R., Wardle, D. (2014)

Plant and microbial responses to nitrogen and phosphorus addition across an elevational gradient in subarctic tundra.

Ecology, 95(7): 1819-1835

Access to the published version may require subscription.

N.B. When citing this work, cite the original published paper.

Permanent link to this version:

http://urn.kb.se/resolve?urn=urn:nbn:se:umu:diva-92270 


\title{
Plant and microbial responses to nitrogen and phosphorus addition across an elevational gradient in subarctic tundra
}

\author{
Maja K. Sundqvist, ${ }^{1,4}$ Zhanfeng Liu, ${ }^{2}$ Reiner Giesler,${ }^{3}$ and David A. Wardle ${ }^{1}$ \\ ${ }^{1}$ Department of Forest Ecology and Management, Swedish University of Agricultural Sciences, SE-90183 Umeå, Sweden \\ ${ }^{2}$ Key Laboratory of Vegetation Restoration and Management of Degraded Ecosystems, South China Botanical Garden, \\ Chinese Academy of Sciences, Guangzhou 510650 China \\ ${ }^{3}$ Climate Impacts Research Centre, Department of Ecology and Environmental Sciences, Umeå University, SE-98107 Abisko, Sweden
}

\begin{abstract}
Temperature and nutrients are major limiting factors in subarctic tundra. Experimental manipulation of nutrient availability along elevational gradients (and thus temperature) can improve our understanding of ecological responses to climate change. However, no study to date has explored impacts of nutrient addition along a tundra elevational gradient, or across contrasting vegetation types along any elevational gradient. We set up a full factorial nitrogen $(\mathrm{N})$ and phosphorus $(\mathrm{P})$ fertilization experiment in each of two vegetation types (heath and meadow) at $500 \mathrm{~m}, 800 \mathrm{~m}$, and $1000 \mathrm{~m}$ elevation in northern Swedish tundra. We predicted that plant and microbial communities in heath or at lower elevations would be more responsive to $\mathrm{N}$ addition while communities in meadow or at higher elevations would be more responsive to $\mathrm{P}$ addition, and that fertilizer effects would vary more with elevation for the heath than for the meadow. Although our results provided little support for these predictions, the relationship between nutrient limitation and elevation differed between vegetation types. Most plant and microbial properties were responsive to $\mathrm{N}$ and/or $\mathrm{P}$ fertilization, but responses often varied with elevation and/or vegetation type. For instance, vegetation density significantly increased with $\mathrm{N}+\mathrm{P}$ fertilization relative to the other fertilizer treatments, and this increase was greatest at the lowest elevation for the heath but at the highest elevation for the meadow. Arbuscular mycorrhizae decreased with P fertilization at $500 \mathrm{~m}$ for the meadow, but with all fertilizer treatments in both vegetation types at $800 \mathrm{~m}$. Fungal to bacterial ratios were enhanced by $\mathrm{N}+\mathrm{P}$ fertilization for the two highest elevations in the meadow only. Additionally, microbial responses to fertilization were primarily direct rather than indirect via plant responses, pointing to a decoupled response of plant and microbial communities to nutrient addition and elevation. Because our study shows how two community types differ in their responses to fertilization and elevation, and because the temperature range across this gradient is $\sim 3^{\circ} \mathrm{C}$, our study is informative about how nutrient limitation in tundra may be influenced by temperature shifts that are comparable to those expected under climate change during this century.
\end{abstract}

Key words: above- and belowground communities; fertilization experiment; fungal-to-bacterial ratios; global warming; plant functional groups; plant-soil linkages.

\section{INTRODUCTION}

Temperature is a major limiting factor for highlatitude communities and ecosystems such as subarctic tundra, and these systems are therefore predicted to be particularly responsive to global warming (IPCC 2007). Since organisms and communities regulate ecosystem processes, understanding how they will respond to longterm warming is essential for predicting the effect of global climate change on tundra ecosystem functioning (Wookey et al. 2009). Increasing elevation is associated with a decline in temperature, so elevational gradients

Manuscript received 9 May 2013; revised 21 November 2013; accepted 26 November 2013. Corresponding Editor: C. V. Hawkes.

${ }^{4}$ Present address: Department of Ecology and Environmental Science, Umeå University, SE-90187 Umeå, Sweden. E-mail: maja.sundqvist@gmail.com. represent powerful natural experiments that may inform about community responses to variation in temperature at the landscape scale when other abiotic factors remain relatively constant (Körner 2007, Sundqvist et al. 2013). As such, several observations have shown that organisms and communities, both above- and belowground, are highly responsive to elevation (and associated changes in climatic factors) in many locations around the world (e.g., Whittaker 1956, Hodkinson 2005, Bahram et al. 2012).

Declining temperatures associated with increasing elevation can directly influence community properties by limiting metabolism and process rates for both plants (Hoch and Körner 2012) and soil microbes (Schinner 1982, Margesin et al. 2008). However, reduced temperatures associated with increasing elevation can also exert indirect effects on organisms and communities (e.g., Hodkinson 2005, Sundqvist et al. 2013). One important 
indirect effect involves impairment of fluxes and biological availability of soil nutrients resulting from reduced temperatures associated with increasing elevation (Vitousek et al. 1988, 1994, Sveinbjörnsson et al. 1995). This can occur, for instance, through the influence of lower temperatures at high elevations on species composition, or the impairment of microbial activity, nutrient inputs, organic matter quality, decomposition, and nutrient mineralization rates (Vitousek et al. 1988, 1994, Sveinbjörnsson et al. 1995, Sundqvist et al. 2011a). We currently have a limited understanding of the mechanistic basis through which this indirect effect of elevation (i.e., via soil nutrient availability) may influence communities in ecosystems that are likely to be heavily impacted by global warming, such as tundra. Since temperature limits soil nutrient mineralization rates, global warming is also expected to significantly enhance nutrient availability in arctic tundra (ACIA 2005). An increased understanding of community responses to the indirect effect of elevation on nutrient availability should therefore provide information on responses of tundra ecosystems to future climate change.

Tundra ecosystems are widely recognized as highly nutrient limited. This has been confirmed through numerous experiments in both alpine and arctic tundra that have revealed strong effects of fertilization on aboveground properties and processes, such as plant biomass, net primary productivity, and plant community composition (Gough et al. 2000, Bret-Harte et al. 2008, Haugwitz and Michelsen 2011). With regard to belowground responses, fertilizer additions in tundra have also been shown to reduce soil carbon (C) storage (Mack et al. 2004), and drive shifts in the relative proportion of bacterial and fungal biomass in variable directions (Rinnan et al. 2013, Wardle et al. 2013). Studies in other ecosystems have also revealed consistent shifts in soil bacterial community structure in response to nitrogen (N) addition (Ramirez et al. 2010), and a greater responsiveness of soil microbes to phosphorus (P) addition under low soil $\mathrm{P}$ availability (Craine et al. 2007) or high $\mathrm{N}$ deposition levels (Liu et al. 2012). Nitrogen is often considered the main limiting nutrient in high-altitude and high-latitude ecosystems (Tamm 1991, Aerts and Chapin 2000), but a growing number of studies suggest that plant productivity for some tundra species and vegetation types is limited by $\mathrm{P}$ or co-limited by $\mathrm{N}$ and P (e.g., Seastedt and Vaccaro 2001, Weintraub 2011, Giesler et al. 2012, Zamin and Grogan 2012). Some studies have also provided evidence for a change in the relative importance of $\mathrm{P}$ vs. $\mathrm{N}$ limitation with elevation (van de Weg et al. 2009). Specifically, results from the Swedish subarctic tundra suggest that $\mathrm{P}$ relative to $\mathrm{N}$ limitation increases with elevation-associated declines in temperature (Sundqvist et al. 2011b). However, no study has tested this experimentally through the use of fertilizer addition in tundra ecosystems. Indeed, to our knowledge the only study to have explicitly tested this across any elevational gradient is Fisher et al. (2013), who applied N and P fertilizers across a tropical forest gradient in the Peruvian Andes and showed that $\mathrm{N}$ limitation increased with elevation.

Here, we use an $\mathrm{N}$ and $\mathrm{P}$ fertilization experiment designed to alleviate $\mathrm{N}$ and/or $\mathrm{P}$ limitation across an established elevational gradient in Swedish subarctic tundra (Sundqvist et al. 2011a, b, 2012, Milbau et al. 2013), to explore how nutrient limitation impacts plant and soil microbial communities across ecosystems that experience contrasting temperature regimes. The Swedish subarctic tundra is a mosaic of different vegetation types, and two functionally contrasting vegetation types, heath and meadow, co-occur at all elevations along our gradient. Heath vegetation is dominated by evergreen and deciduous dwarf shrubs, while the meadow vegetation is dominated by faster growing plants such as forbs, graminoids, and sedges. The heath vegetation has been shown to have lower soil $\mathrm{pH}$ and $\mathrm{N}$ availability, but higher $\mathrm{P}$ availability and soil fungal-to-bacterial ratios compared to meadow vegetation (Björk et al. 2007, Eskelinen et al. 2009, Sundqvist et al. 2011a, Giesler et al. 2012). Plant and microbial communities for these two vegetation types also display vastly different responses to elevation (Sundqvist et al. 2011a). Previous work in our study system has also shown that foliage and leaf litter N:P ratios increase with elevation for both vegetation types, indicating an overall increase in the relative importance of $\mathrm{P}$ vs. $\mathrm{N}$ limitation with increasing elevation (Sundqvist et al. 2011b). Further, while soil fungal-to-bacterial ratios increase, and available concentrations of $\mathrm{N}$ and $\mathrm{P}$ decline with increasing elevation for the heath, these properties show idiosyncratic responses to elevation for the meadow (Sundqvist et al. 2011a). Because responses of soil abiotic, plant, and microbial properties to elevation have been described for both the heath and the meadow (Sundqvist et al. $2011 a, b)$, this system provides strong opportunities for studying the response of highly contrasting plant and microbial communities to the alleviation of $\mathrm{N}$ and $\mathrm{P}$ limitation across the same elevational gradient.

It is widely recognized that the plant and soil microbial subsystems are often interlinked (Wardle 2002, Bardgett and Wardle 2010). For example, plant species adapted to more fertile soils, which produce high-quality litter, are generally associated with a more bacterial-based soil microbial community compared to plants growing on less fertile soils, which often have a relatively higher dominance of fungi (e.g., Coleman et al. 1983, Eskelinen et al. 2009). However, some recent studies have pointed to a decoupled response of plant and microbial communities to fertilization (Wardle et al. 2013), while others have not (Suding et al.2008); we still know very little about the generality of this decoupled response. In addition, to our knowledge, no study has explored the effect of fertilization for both plant and microbial communities at multiple points across the same elevational gradient. We used this study system to 
test the following three hypotheses. (1) Plant and soil microbial communities at lower elevations will be more responsive to $\mathrm{N}$ addition, and higher elevational communities will be more responsive to $\mathrm{P}$ addition. We base this on previous measures of plant tissue N:P ratios across the study system, which suggest increasing $\mathrm{P}$ relative to $\mathrm{N}$ limitation with increasing elevation (Sundqvist et al. 2011b). (2) Phosphorus fertilization will have a greater effect on plant and microbial properties in the meadow, and $\mathrm{N}$ fertilization will have a greater impact in the heath. This is based on previous observations that higher concentrations of mineral $\mathrm{N}$ occur in the meadow soils and higher mineral $\mathrm{P}$ concentrations occur in the heath soils (Sundqvist et al. 2011a). (3) The influence of $\mathrm{N}$ and $\mathrm{P}$ addition (either singly or in combination) on plant and microbial properties will be determined by interactive effects between elevation and vegetation type (heath vs. meadow), because fertilizer effects will change more with elevation for the heath than for the meadow. This third hypothesis is based on previous findings that concentrations of soil-available nutrients decline unidirectionally with elevation for the heath but not for the meadow (Sundqvist et al. 2011a). We tested these hypotheses in the Swedish subarctic tundra, which contains large gradients of elevation and a mosaic of contrasting vegetation types, and which is therefore highly regulated by local-scale variation in temperature and nutrient availability. Using this study system we aim to advance our mechanistic understanding of how community properties and aboveground-belowground linkages in these ecosystems may respond to global change.

\section{Materials And Methods}

\section{Study site}

This study was conducted on the northeast facing slope of Mt. Suorooaivi (1193 m above sea level) situated $20 \mathrm{~km}$ southeast from Abisko, northern Sweden $\left(68^{\circ} 21^{\prime} \mathrm{N}, 18^{\circ} 49^{\prime} \mathrm{E}\right)$, previously described by Sundqvist et al. (2011a). The climate in this area is subarctic, with a growing season of approximately three months. Previous measurements of air temperature during the summer months have shown that temperature declines by $\sim 3^{\circ} \mathrm{C}$ from $400 \mathrm{~m}$ to $1000 \mathrm{~m}$ across the study site (Sundqvist et al. 2011a, $b$; Appendix A). The mean annual precipitation measured in the proximity of the study area (Abisko Scientific Research Station) was $310 \mathrm{~mm}$ for the period 1913-2000, with the highest mean monthly precipitation in July $(51 \mathrm{~mm})$ and the lowest in April $(12 \mathrm{~mm})$ (Kohler et al. 2006). Summer precipitation at Mt Suorooaivi ranges between 230 and $290 \mathrm{~mm}$, and has been shown to vary little across elevations in the proximity of the study area (Karlsson et al. 2005), as well as across two contrasting elevations in the study site itself (Sundqvist 2011). At the study site, the bedrock consists of salic igneous rocks and quartic and phyllitic hard schists. The forest line, formed by Betula pubescens ssp. czerepanovii (mountain birch), is situated at an elevation of 500-600 $\mathrm{m}$ at the study site. Two co-dominant vegetation types occur in a mosaic at all elevations: meadow (dominated by forbs, graminoids, and sedges) and heath (dominated by deciduous and evergreen dwarf shrubs). For more details on the study system see Sundqvist et al. (2011a, $b$, 2012).

\section{Experimental setup}

In July 2008, a total of 96 plots (each $1 \times 1 \mathrm{~m}$, with the outer $10 \mathrm{~cm}$ as a buffer) were established, i.e., 16 plots in heath vegetation and 16 plots in meadow vegetation at each of three elevations $(500,800$, and $1000 \mathrm{~m})$, in the proximity of plots used in previous studies in this system (Sundqvist et al. 2011a, b, 2012; see Plate 1). The size of each plot is characteristic of the minimum size of patches of each vegetation type across the study site, and is of a sufficient size for assessing vegetation responses in both vegetation types (Sundqvist et al. 2011a). Within each elevation, the mean distance of each plot to the nearest plot for the same treatment is $\sim 10 \mathrm{~m}$ (and the mean distance between the two most distant plots is $\sim 100 \mathrm{~m}$ ). Due to high spatial heterogeneity over very short distances (often on the order of a few meters) in microtopography and soil fertility characteristic of these communities (Björk et al. 2007), it is expected that the $10 \mathrm{~m}$ distance among plots is sufficient to ensure adequate independence among them (Sundqvist et al. 2011a, 2012). Plots at the $500 \mathrm{~m}$ elevation were situated in open birch forest immediately below the forest line, and plots at $800 \mathrm{~m}$ and $1000 \mathrm{~m}$ were devoid of trees. Gradients of this type are extremely useful for exploring the role of temperature and associated changes in climate in influencing ecosystem properties when other abiotic factors do not co-vary with elevation (Körner 2007, Sundqvist et al. 2013). In this study system, all plots have approximately the same aspect (northeastfacing slope), and parent material is independent of elevation, so that climate is the principal abiotic factor that varies with elevation (Sundqvist et al. 2011a).

At each elevation, in each vegetation type, four replicates of the 16 plots were each randomly assigned to one of four treatments, i.e., Control (unamended), $\mathrm{N}$ addition, $\mathrm{P}$ addition, and $\mathrm{N}+\mathrm{P}$ addition. To alleviate $\mathrm{N}$ and $\mathrm{P}$ limitation for each plot that received $\mathrm{N}$ and $\mathrm{P}$ addition, fertilizers were added annually from 2008 to 2010 in the amount of $10 \mathrm{~g} \mathrm{~N} \cdot \mathrm{m}^{-2} \cdot \mathrm{yr}^{-1}$ as $\mathrm{NH}_{4} \mathrm{NO}_{3}$, and $5 \mathrm{~g} \mathrm{P} \cdot \mathrm{m}^{-2} \cdot \mathrm{yr}^{-1}$ as superphosphate $\left(\mathrm{Ca}\left(\mathrm{H}_{2} \mathrm{PO}_{4}\right)_{2} \cdot \mathrm{H}_{2} \mathrm{O}\right)$, which is in line with rates used in previous studies on nutrient limitation in arctic tundra (e.g., Jonasson 1992, Chapin et al. 1995, Mack et al. 2004, Rinnan et al. 2007), as well as other ecosystems (Vitousek 2004). Fertilizers were added for the first time on 26 July 2008. For the two following years, half of the total annual amount was added when all plots were snow free $(25$ June 2009 and 8 June 2010), and half was added three weeks later (i.e., 16 July 2009 and 29 June 2010). 


\section{Vegetation survey}

Tundra vegetation is well known to be responsive to nutrient additions within a two-year period (e.g., Chapin and Shaver 1985, Jonasson 1992). In order to assess the effect of fertilizer addition after two years on vegetation properties across our study site, the total cover of each species was measured by point quadrat analysis (Goodall 1952), in each plot, over the period 8-20 July 2010. This was performed by recording the total number of times the vegetation of each species was intercepted from a total of 100 downward-projecting points in each plot (Wardle et al. 2003) using the inner $80 \times 80 \mathrm{~cm}$ of each plot, with the outer $10 \mathrm{~cm}$ serving as a buffer zone. This cover data was also used for calculating Shannon's diversity index (hereafter "Shannon's diversity") and total vegetation density (Sundqvist et al. 2011a), as well as the cover of each plant functional group, i.e., forbs, graminoids, sedges, deciduous and evergreen dwarf shrubs, pteridophytes. Further, total species richness was also recorded by noting all plant species present within this $80 \times 80 \mathrm{~cm}$ area, including those not intercepted by any points.

\section{Soil sampling and analysis}

Fresh soil was sampled from each plot after two years, over 23-27 August 2010. In each plot, at least five samples were taken to ensure a minimum of $0.2 \mathrm{~L}$ of humus. The whole humus layer was sampled using a 45 $\mathrm{mm}$ diameter soil core, and the depth of the humus layer for each core was recorded. All cores collected in each plot were bulked into one composite sample and brought to the laboratory on the same day as sampling, where they were kept cold $\left(+2^{\circ} \mathrm{C}\right)$ for a maximum of $24 \mathrm{~h}$ before further analysis. For each bulked sample from each plot, the humus soil was homogenized using a 4$\mathrm{mm}$ sieve. Soil $\mathrm{pH}$ was measured in a soil:water suspension $(50 \mathrm{~mL}$ deionized water and $6 \mathrm{~g}$ fresh mass soil shaken overnight followed by sedimentation for one hour). Gravimetric soil moisture was determined after drying $\left(105^{\circ} \mathrm{C}, 24\right.$ hours) and soil organic matter (OM) content was determined by loss on ignition $\left(550^{\circ} \mathrm{C}\right.$, four hours). To measure soil-available concentrations of $\mathrm{N}$ $\left(\mathrm{NH}_{4}-\mathrm{N}\right.$ and $\left.\mathrm{NO}_{3}-\mathrm{N}\right)$ and $\mathrm{P}\left(\mathrm{PO}_{4}-\mathrm{P}\right)$ for each plot, a subsample of $5 \mathrm{~g}$ fresh mass of soil was extracted in 80 $\mathrm{mL}$ of $1 \mathrm{~mol} / \mathrm{L} \mathrm{KCl}$, and concentrations were determined by colorimetry on an AutoAnalyser III (SEAL Analytical, Kontram OmniProcess AB, Solna, Sweden). All mineral nutrient concentrations are expressed as milligram per gram of organic matter. A subsample of dried $\left(70^{\circ} \mathrm{C}\right.$, three days) and ground (ball mill; Retsch MM 301, Haan, Germany) soil from each plot was analyzed for total \% carbon (C), N (Leco TruSpec CN Furnace, Leco, St. Joseph, Michigan, USA) and P (nitric acid : perchloric acid digestion followed by inductively coupled plasma analysis) (Thompson and Wood 1982).

Soil microbial community composition was characterized for a subsample of each bulked soil sample by using phospholipid fatty acid (PLFA) analysis as described by Frostegård et al. (1991) with minor modifications. Briefly, $0.5 \mathrm{~g}$ of fresh soil samples were extracted in chloroform-methanol-phosphate buffer (1:2:0.8 volume/volume/volume), and the extracted lipids were fractionated into neutral lipids, glycolipids, and polar lipids on silic acid columns by successive elution with chloroform, acetone, and methanol. The methanol fraction (containing phospholipids) was subjected to mild alkaline methanolysis to transform the fatty acids into free methyl esters and analyzed on a gas chromatograph (GC), equipped with a flame ionization detector. The PLFAs i15:0, a15:0, i16:0, 16:1 $\omega 9$,

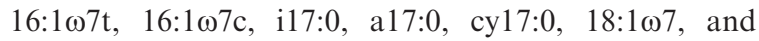
cy 19:0 were used to indicate relative bacterial biomass, the PLFA 18:2 16 was used as an indicator of relative fungal biomass (Frostegård and Bååth 1996) and the PLFA 16:1 $\omega 5$ was used as an indicator of relative arbuscular mycorrhizal (AM) biomass (Olsson 1999). The PLFAs 10Me17:0 and 10Me18:0 were used to indicate relative actinomycete biomass (Lechevalier 1977, Kroppenstedt 1985). The PLFAs chosen to represent fungi and the sum of the PLFA markers chosen to represent bacteria were used to calculate the fungal-to-bacterial ratio (Frostegård and Bååth 1996) for each plot. All PLFAs were calculated as nanomoles per gram of organic matter (OM).

\section{Statistical analysis}

The effects of vegetation type, elevation, $\mathrm{N}$ addition, $P$ addition, and all possible interactions among these factors, on plant, soil microbial, and soil abiotic variables were analyzed using four-way ANOVA. Whenever ANOVA yielded significant effects we used Duncan's test at $P=0.05$ to assess differences among means. To further evaluate the response of the plant and microbial communities to these factors as well as their relationships with each other and with soil abiotic properties, multivariate approaches were used. First, detrended correspondence analysis (DCA) was applied to the plant species data set, which revealed a gradient length of the first axis $>5 \mathrm{SD}$, indicating a unimodal response (ter Braak and Šmilauer 2002). Thus, canonical correspondence analysis (CCA) was applied to the plant species data set using soil properties as explanatory environmental variables. Each explanatory variable that explained an additional amount of variation at $P<0.05$ was retained by manual forward selection using Monte Carlo permutations (999 unrestricted permutations) (ter Braak and Šmilauer 2002). The sample scores for the first and the second axis for all plots derived from the CCA were further analyzed using four-way ANOVAs as described above to test the effects of vegetation type, elevation, $\mathrm{N}$ addition, and $\mathrm{P}$ addition on plant community composition. The microbial data set (PLFAs) was first subjected to DCA, which revealed a gradient length of the first axis $<1 \mathrm{SD}$, indicating a linear response (ter Braak and Šmilauer 2002). As such, the microbial data set was further subjected to a partial 


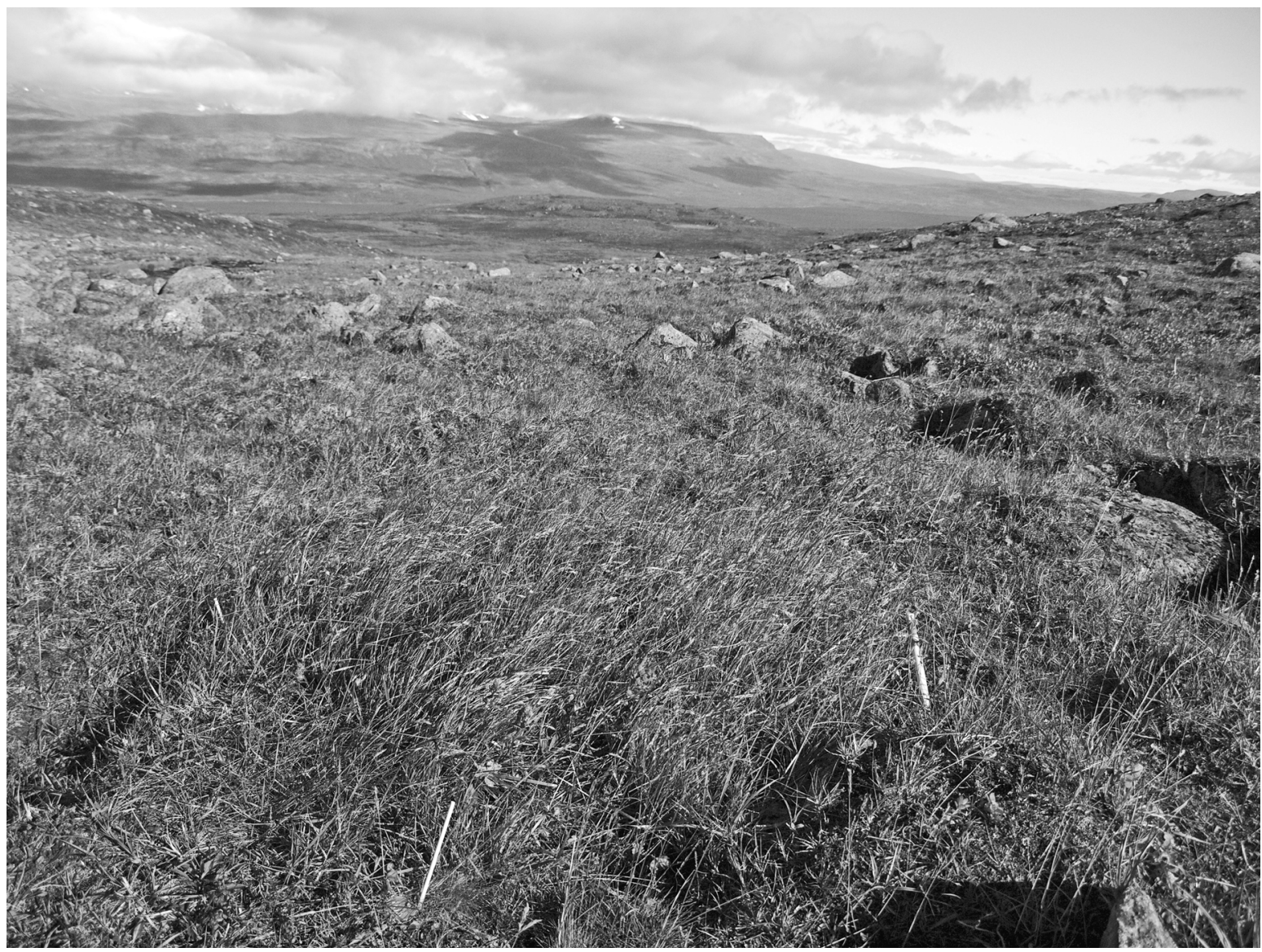

Plate 1. Meadow vegetation at $800 \mathrm{~m}$ at the northeast facing slope of Mt. Suorooaivi, Sweden. Photo credit: Tyler Logan, September 2012.

redundancy analysis (RDA) using soil abiotic properties and plant functional group cover as explanatory environmental variables, with species standardized by error variance (Borcard et al. 1992, ter Braak and Šmilauer 2002). The most discriminating combination of environmental variables was selected by the "forward selection" Monte Carlo procedure, exactly as just described. The sample scores derived from the RDA were further analyzed by four-way ANOVAs to test the effects of vegetation type, elevation, and fertilization (N, $\mathrm{P}$ addition) on soil microbial community composition. All univariate analyses were performed in SPSS Statistics 20.0 (IBM SPSS 2011) and all multivariate analyses were performed using CANOCO for Windows 4.5 (ter Braak and Šmilauer 2002).

\section{REsUlts}

\section{Plant community properties}

Both species richness and Shannon's diversity were highest for the meadow, where they peaked at $800 \mathrm{~m}$, while for the heath they were lowest at $800 \mathrm{~m}$ (Fig. 1AD: Appendix B). Fertilizer treatments by themselves had no overall effect on either variable, but there was a significant $\mathrm{N} \times$ vegetation type $\times$ elevation interaction for Shannon's diversity, because at $500 \mathrm{~m}$ for the heath and $800 \mathrm{~m}$ for the meadow, Shannon's diversity was significantly reduced by $\mathrm{N}+\mathrm{P}$ fertilization relative to the treatments without $\mathrm{N}$ addition (Fig. 1A-D; Appendix B). Vegetation density did not differ between vegetation types, but did differ among elevations; overall, density was highest at the $500-\mathrm{m}$ elevation for the heath, and at the 500- and 1000-m elevations for the meadow (Fig. 1E, F; Appendix B). Vegetation density was significantly increased by $\mathrm{N}+\mathrm{P}$ fertilization relative to the other treatments, and this increase was greatest at the lowest elevation for the heath and at the highest elevation for the meadow (Fig. 1E, F; N $\times \mathrm{P} \times$ vegetation type $\times$ elevation interaction: $F=5.2, \mathrm{df}=2,72, P=0.008$ ).

Deciduous and evergreen shrub cover was highest on heath, while cover for all other plant functional groups was highest on the meadow (Fig. 2; Appendix B). There was also an interactive effect of elevation $\times$ vegetation type on all plant functional groups (Appendix B). For the heath, pteridophytes, deciduous shrubs, graminoids, and forbs declined, while evergreen shrubs and sedges increased with increasing elevation. Conversely, for the 

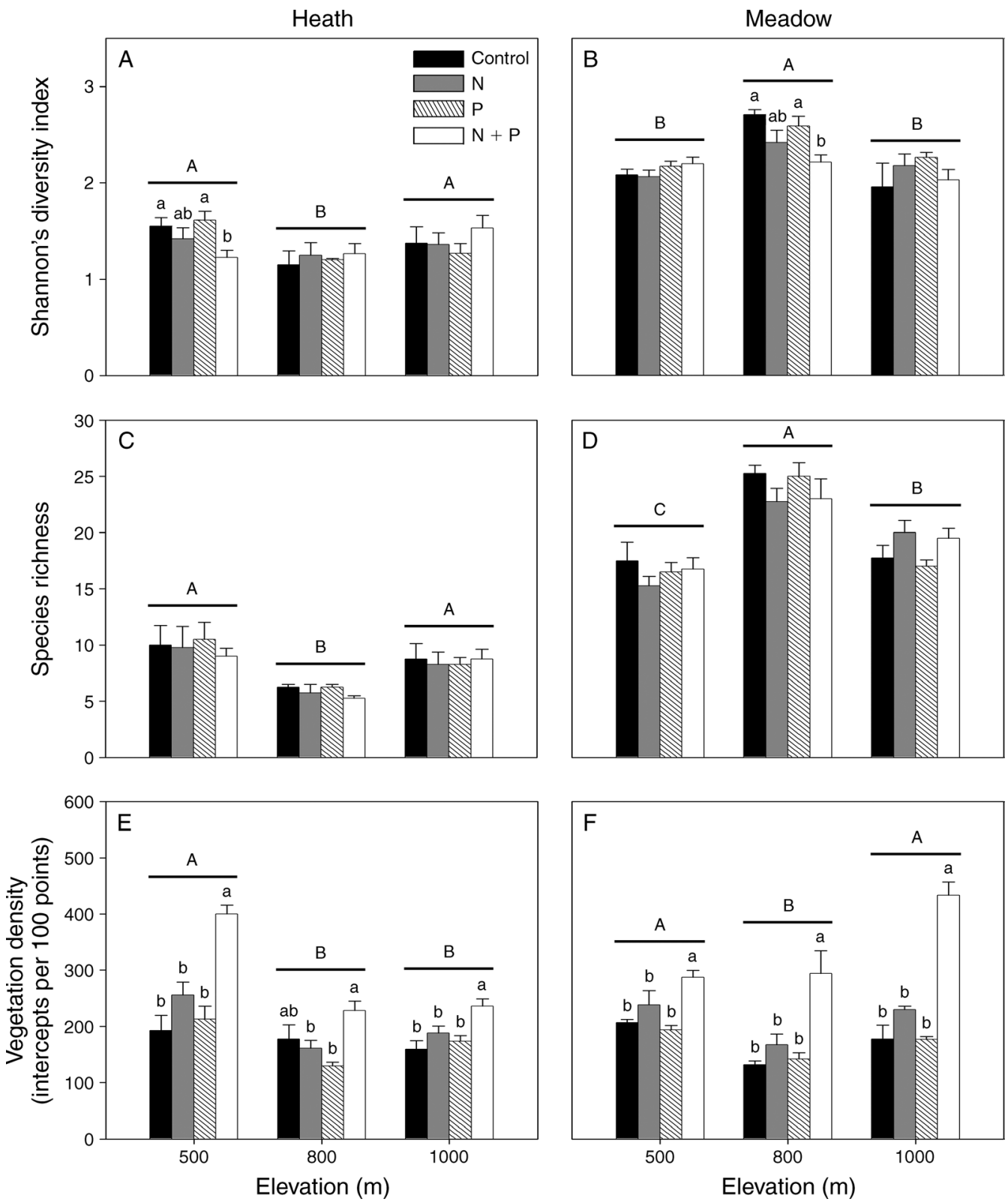

FIG. 1. (A, B) Shannon's diversity index, (C, D) species richness, and (E, F) vegetation density in plots without fertilizer addition (Control), or amended with $\mathrm{N}, \mathrm{P}$, or $\mathrm{N}+\mathrm{P}$, for subarctic heath and meadow vegetation across an elevational gradient. Error bars represent $+\mathrm{SE}(N=4)$. Within each panel, groups of four bars with the same capital letters above them are not significantly different at $P<0.05$ (Duncan's test). Within each group of four bars, bars with the same lowercase letters above them are not significantly different at $P<0.05$; letters are not presented when none of the four bars differs significantly from any of the others (Duncan's test). ANOVA results are given in Appendix B.

meadow, deciduous and evergreen shrubs, graminoids, and sedges increased, while pteridophytes and forbs declined with increasing elevation (Fig. 2; Appendix B). All plant functional groups were responsive to $\mathrm{N}$ and/or $\mathrm{P}$ fertilization (except for pteridophytes) and responses often differed significantly among fertilizer treatments, vegetation types, and elevations (Fig. 2; Appendices B and $\mathrm{C}$ ). For the heath at the $500-\mathrm{m}$ elevation only, deciduous and evergreen shrubs were significantly reduced by $\mathrm{N}+\mathrm{P}$ addition, and evergreen shrubs were also reduced by $\mathrm{N}$ added alone. Meanwhile, graminoid cover in the heath was increased by $\mathrm{N}$ and $\mathrm{N}+\mathrm{P}$ fertilization at $500 \mathrm{~m}$ and by $\mathrm{N}+\mathrm{P}$ fertilization at 1000 $\mathrm{m}$ (Fig. 2; Appendices B and C). For the meadow, deciduous shrub cover was lowest in the $\mathrm{N}+\mathrm{P}$ fertilization treatment at $800 \mathrm{~m}$, and in the $\mathrm{N}$ and $\mathrm{N}+$ $\mathrm{P}$ fertilization treatments at $1000 \mathrm{~m}$, while evergreen shrub cover was lowest in the $\mathrm{N}$ and $\mathrm{N}+\mathrm{P}$ fertilization 

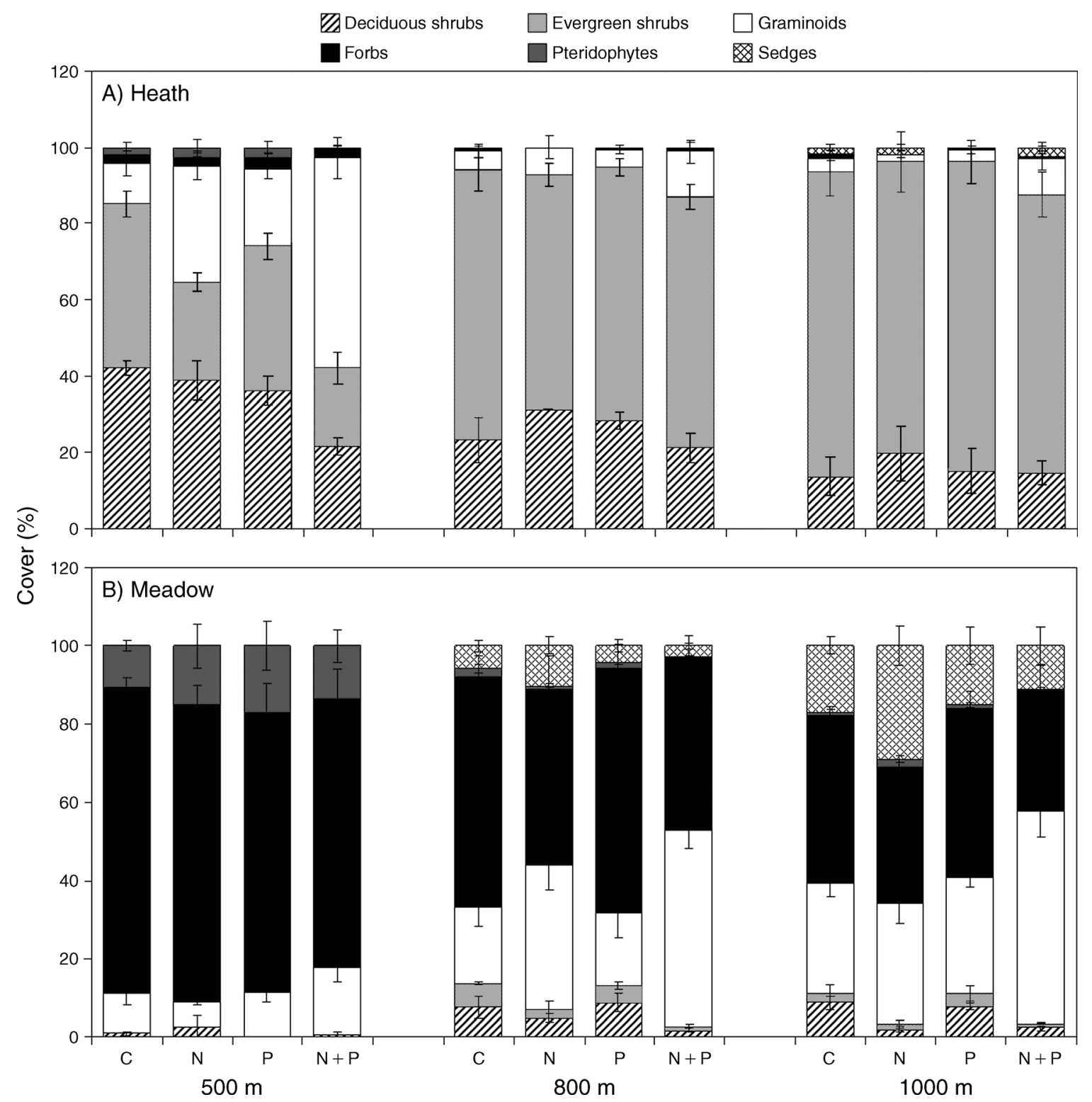

FIG. 2. The mean percentage cover $( \pm \mathrm{SE})$ of plant functional groups in plots without fertilizer addition (Control) or amended with $\mathrm{N}, \mathrm{P}$, or $\mathrm{N}+\mathrm{P}$ for (A) subarctic heath and (B) meadow along an elevational gradient. ANOVA results are given in Appendix $\mathrm{B}$, and actual values with SEs are given in Appendix C.

at $800 \mathrm{~m}$. Further, in the meadow, graminoid cover was highest in the $\mathrm{N}+\mathrm{P}$ fertilization treatment at all elevations, while sedge cover was lowest in the $\mathrm{N}+\mathrm{P}$ fertilization treatment at $800 \mathrm{~m}$ and $1000 \mathrm{~m}$ (Fig. 2; Appendices B and C). Overall, forbs were reduced by $\mathrm{N}$ fertilization, and this reduction was greatest for the meadow (significant $\mathrm{N} \times$ vegetation type interaction; Fig. 2; Appendix B).

\section{Soil microbial community composition}

Overall, actinomycete, AM, and bacterial biomasses were highest for the meadow, while fungal biomass and the fungal-to-bacterial ratio were highest for the heath (Fig. 3;
Appendix D). For both vegetation types, fungal biomass was highest at $800 \mathrm{~m}$, the fungal-to-bacterial ratio was lowest at $500 \mathrm{~m}$ and the bacterial biomass was unresponsive to elevation (Fig. 3). While there was a significant effect of elevation on AM biomass according to ANOVA (Appendix D), post hoc analyses revealed no significant differences among elevations (data not shown). There was a significant overall effect of $\mathrm{N}$ and/or $\mathrm{P}$ fertilization on most microbial properties, and the effect of fertilization was often dependent on elevation and/or vegetation type (Fig. 3; Appendix D). Overall, $\mathrm{N}$ fertilization slightly increased fungal biomass and $\mathrm{P}$ addition decreased bacterial biomass, but this was not statistically significant for either 

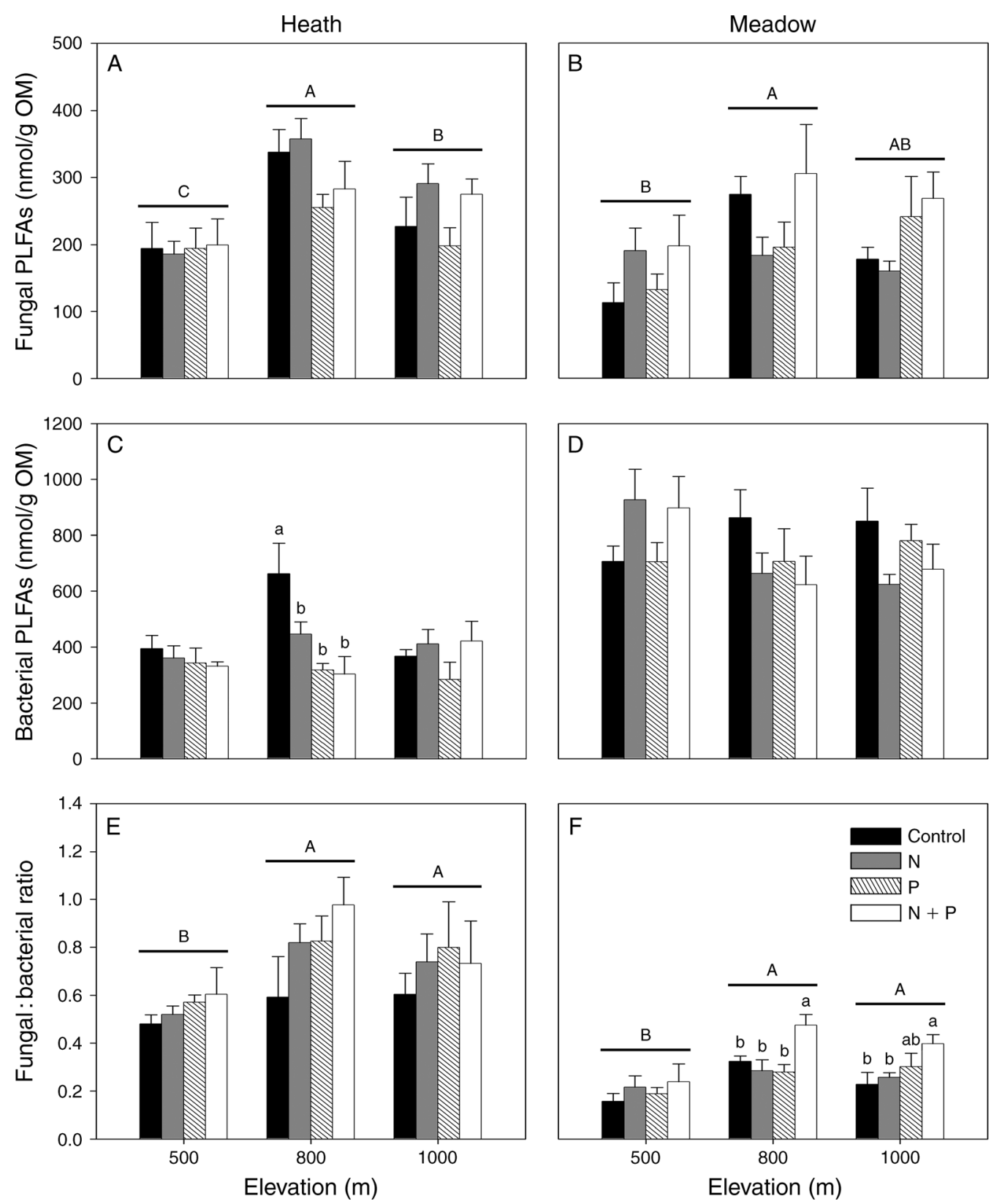

FIG. 3. (A, B) Fungal biomass (phospholipid fatty acids [PLFA]), (C, D) bacterial biomass, and (E, F) fungal: bacterial ratio in plots without fertilizer addition (Control) or amended with $\mathrm{N}, \mathrm{P}$, or $\mathrm{N}+\mathrm{P}$ for subarctic heath and meadow vegetation across an elevational gradient. Error bars represent $+\mathrm{SE}(N=4)$. Within each panel, groups of four bars with the same capital letters above them are not significantly different at $P<0.05$ (Duncan's test). Within each group of four bars, bars with the same lowercase letters above them are not significantly different at $P<0.05$; letters are not presented when none of the four bars differs significantly from any of the others (Duncan's test). ANOVA results are given in Appendix D. OM is organic matter.

variable. There was also an interactive effect of $\mathrm{P}$ fertilization and vegetation type on fungal biomass (Fig. 3; Appendix D). Specifically for the heath, at the $800-\mathrm{m}$ elevation bacterial biomass was reduced by all fertilizer additions (Fig. 3), and at $1000 \mathrm{~m}$, actinomycete biomass was increased by $\mathrm{N}$ fertilization (data not shown; Appendix D). Meanwhile, for the meadow, at 800 and $1000 \mathrm{~m}$ the fungal-to-bacterial ratio was increased by $\mathrm{N}+\mathrm{P}$ fertiliza- tion, while the bacterial and fungal biomass were both unresponsive to fertilization within each elevation (Fig. 3). Further for the meadow, AM biomass was reduced by $\mathrm{P}$ fertilization at $500 \mathrm{~m}$, and for both vegetation types AM biomass was reduced by all fertilizer treatments at the 800 m elevation (elevation $\times$ P interaction: $F=3.2, \mathrm{df}=2,72, P$ $=0.048, \mathrm{~N} \times$ P interaction: $F=5.9, \mathrm{df}=1,72, P=0.017$; data not shown). 

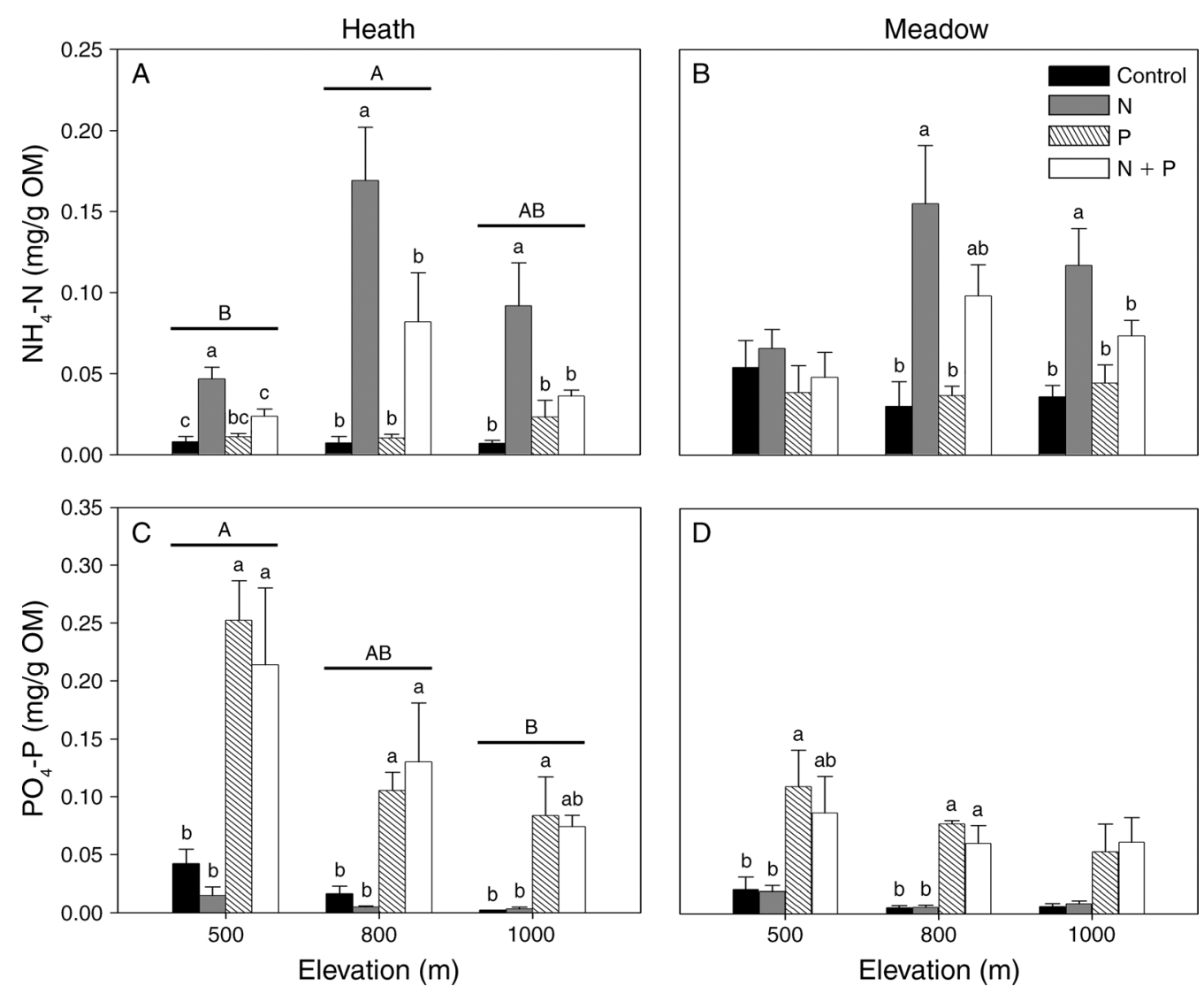

FIG. 4. Concentrations of (A, B) soil $\mathrm{NH}_{4}-\mathrm{N}$ and (C, D) $\mathrm{PO}_{4}-\mathrm{P}$ in plots without fertilizer additions (Control) or amended with $\mathrm{N}, \mathrm{P}$, or $\mathrm{N}+\mathrm{P}$ in subarctic heath and meadow vegetation along an elevational gradient. Error bars represent $+\mathrm{SE}(N=4)$. Within each panel, groups of four bars with the same capital letters above them are not significantly different at $P<0.05$ (Duncan's test). Within each group of 4 bars, bars with the same lowercase letters above them are not significantly different at $P<0.05$; letters are not presented when none of the four bars differs significantly from any of the others (Duncan's test). ANOVA results are given in Appendix D.

\section{Soil abiotic properties}

Overall, total soil $\mathrm{C}(\%), \mathrm{N}: \mathrm{P}$ ratios, and $\mathrm{PO}_{4}-\mathrm{P}$ concentrations were highest for the heath, and $\mathrm{pH}, \mathrm{P}$, and $\mathrm{NH}_{4}-\mathrm{N}$ concentrations were highest for the meadow (Fig. 4; Appendix $\mathrm{E}$ and $\mathrm{F}$ ). For the heath, $\mathrm{N}$ was highest at 500 and $800 \mathrm{~m}, \mathrm{NH}_{4}-\mathrm{N}$ concentrations were highest at $800 \mathrm{~m}$ and lowest at $500 \mathrm{~m}$, and $\mathrm{PO}_{4}-\mathrm{P}$ concentrations declined with increasing elevation, and no other abiotic soil variables revealed any simple relationships with elevation for either vegetation type (Fig. 4; Appendix E and F). Phosphorus fertilization generally increased soil $\mathrm{P}$ and $\mathrm{PO}_{4}-\mathrm{P}$ concentrations and reduced the N:P ratio (Fig. 4; Appendices E and F). There was also a significant interactive effect of $P$ addition and elevation on $\mathrm{PO}_{4}-\mathrm{P}$ concentrations because the increase in $\mathrm{PO}_{4}-\mathrm{P}$ was greatest at the lowest elevation (Fig. 4; Appendix E). Meanwhile, $\mathrm{N}$ fertilization added alone significantly increased $\mathrm{NH}_{4}-\mathrm{N}$ concentrations, especially at mid-elevations (significant $\mathrm{N} \times$ elevation interaction), but this increase was mostly not significant when $\mathrm{P}$ was added together with $\mathrm{N}$ (significant $\mathrm{N} \times \mathrm{P}$ interaction; Fig. 4; Appendix E). There was a significant interactive effect of $\mathrm{P}$ addition and vegetation type on $\mathrm{PO}_{4}-\mathrm{P}$ because responses of $\mathrm{PO}_{4}-\mathrm{P}$ to fertilization were overall greater for the heath than for the meadow (Fig. 4; Appendix E). Further, relative to the control, $\mathrm{pH}$ was reduced by $\mathrm{N}+\mathrm{P}$ fertilization at $500 \mathrm{~m}$ and increased by $\mathrm{N}$ fertilization at $800 \mathrm{~m}$ for the heath, while it was reduced by $\mathrm{N}+\mathrm{P}$ fertilization relative to the control and $\mathrm{N}$ fertilization plots at $800 \mathrm{~m}$ for the meadow (significant $\mathrm{N} \times \mathrm{P} \times$ elevation interaction; Appendices $\mathrm{E}$ and $\mathrm{F}$ ). Concentrations of $\mathrm{NO}_{3}-\mathrm{N}$ were only detected in $56 \%$ of the samples (data not shown). For the heath, the lowest detectable $\mathrm{NO}_{3}-\mathrm{N}$ concentrations were found in control plots at $1000 \mathrm{~m}(0.07 \pm 0.001 \mu \mathrm{g} / \mathrm{g} \mathrm{OM}[$ mean $\pm \mathrm{SE}], n=$ 2) and the highest in $\mathrm{N}+\mathrm{P}$ addition plots at $800 \mathrm{~m}(0.6$ $\pm 0.1 \mu \mathrm{g} / \mathrm{g} \mathrm{OM}, n=3$ ). For the meadow, the lowest detectable $\mathrm{NO}_{3}-\mathrm{N}$ concentrations were found in control plots at $1000 \mathrm{~m}(0.8 \pm 0.5 \mu \mathrm{g} / \mathrm{g} \mathrm{OM}, n=3)$ and the highest in $\mathrm{N}$ addition plots at $1000 \mathrm{~m}(2.4 \pm 0.8 \mu \mathrm{g} / \mathrm{g}$ $\mathrm{OM}, n=4)$. No $\mathrm{NO}_{3}-\mathrm{N}$ was detected in any $\mathrm{P}$ addition plots at $500 \mathrm{~m}$ for either vegetation type, in any control 


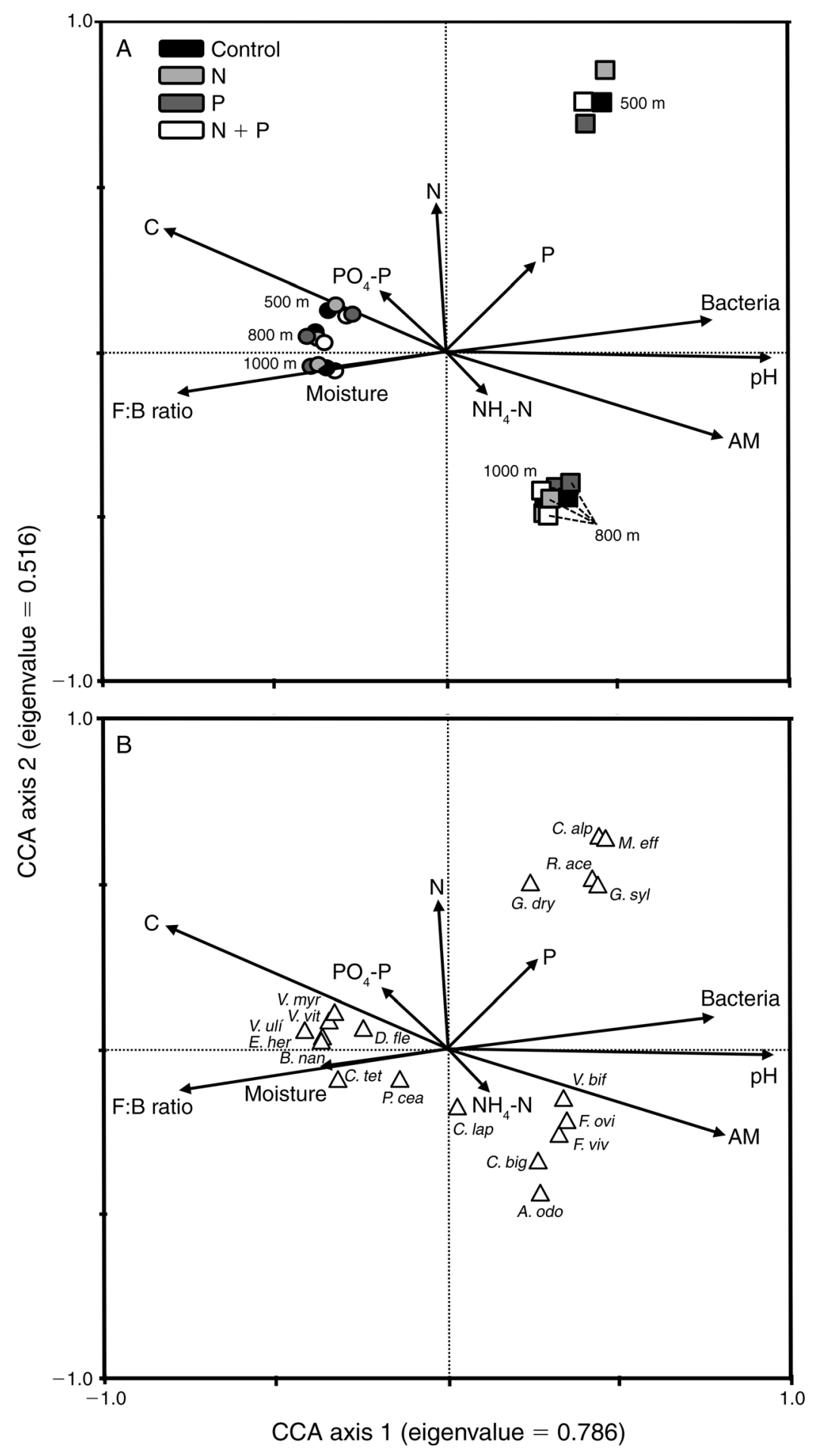

FIG. 5. Canonical correspondence analysis of plant community composition constrained by soil properties. (A) Biplot displaying means of the axis scores for each fertilizer treatment at each elevation within each vegetation type, and environmental (soil abiotic and biotic) variables. Square symbols are meadow plots and circles are heath plots. Whenever Duncan's post hoc test at $P=0.05$ revealed significant differences among elevations, and among plots within elevations and vegetation types, these are presented in the results text. (B) Biplot of species and environmental (soil abiotic and biotic) variables. Species with $\geq 20 \%$ cover in one or more plots are shown: A. odo=Anthoxanthum odoratum, B. nan =Betula nana, C. alp = Cicerbita alpina, C. big $=$ Carex bigelowii, $C$. lap = Calamagrostis lapponica, C. tet $=$ Cassiope tetragona, D. Ale $=$ Deschampsia flexuosa, E. her $=$ Empetrum hermaphroditum, $F$. ovi = Festuca ovina, $F$. viv = Festuca vivipara, G. dry =Gymnocarpium dryopteris, G. syl=Geranium sylvaticum, M. eff = Milium effusum, $P$. cae $=$ Phyllodoce caerulea, $R$. ace $=$ Rumex acetosa, V. bif $=$ Viola biflora, $V$. myr $=$ Vaccinium myrtillus, 
plots in meadow at $500 \mathrm{~m}$, or in any $\mathrm{P}$ addition plots in meadow at $800 \mathrm{~m}$.

\section{Linking vegetation and soil microbial data to soil properties}

The CCA for the plant community data revealed that axis 1 was clearly separated by vegetation type, with $\mathrm{pH}$ and bacterial and AM biomass associated with meadow plots and the fungal-to-bacterial ratio, soil $\mathrm{C}$, and moisture content associated with heath plots (Fig. 5A, B). Plots at different elevations were separated along axis 2 by soil $\mathrm{N}$ (associated with the $500-\mathrm{m}$ elevation for both vegetation types), $\mathrm{P}$ (associated with the meadow at 500-m elevation), $\mathrm{C}$ and $\mathrm{PO}_{4}-\mathrm{P}$ (associated with the heath at 500-m elevation), and $\mathrm{NH}_{4}-\mathrm{N}$ (associated with the meadow at 800 and $1000 \mathrm{~m}$ ) (Fig. 5A). The CCA also showed that certain plant species were more associated with specific elevations, and this effect was stronger for the meadow than for the heath (Fig. 5B); specifically for the meadow plots, species composition below the tree line at $500 \mathrm{~m}$ differed greatly from that of the other two elevations. The ANOVAs revealed that there were no main effects of $\mathrm{N}$ and $\mathrm{P}$ addition on axis 1 and 2 scores derived from CCA (Appendix B). However, there was a significant interactive effect of $\mathrm{P}$ addition and vegetation type on axis 1 scores $(F=4.1$, df $=1,72, P=0.046)$, because $\mathrm{P}$ fertilization increased these scores for the heath but reduced them for the meadow (although this was not significant within vegetation types). According to the post hoc tests, the $500 \mathrm{~m}$ elevation differed significantly from the 800 and $1000 \mathrm{~m}$ elevations along axis 1 and 2 for the meadow, and all elevations differed significantly from each other along both axes for the heath (Fig. 5A).

Partial RDA for the soil microbial data showed that axis 1 was mainly separated by forbs and $\mathrm{pH}$ (which were greater in meadow plots), and by $\mathrm{C}$ (which was greater in heath plots) (Fig. 6A, B). Meanwhile, plots at different elevations were separated along axis 2 by soil $\mathrm{N}$ (greatest in 500-m plots), sedges (greatest in 1000-m meadow plots), and soil moisture (greatest in 1000-m heath plots). Some PLFA markers were also associated with particular vegetation types and elevations (Fig. 6B). For instance, bacterial markers were mainly associated with the meadow, the fungal marker (18:206) was associated with higher elevations for the heath, and the $\mathrm{AM}$ and actinomycete markers with high elevations for the meadow. The ANOVAs revealed that axis 1 scores from the RDA were significantly affected by $\mathrm{P}$ and vegetation type, as well as interactive effects of $\mathrm{N} \times$ elevation, and $\mathrm{N} \times$ vegetation type $\times$ elevation (Appendix D). As such, axis 1 scores differed significantly between heath and meadow and increased overall with $\mathrm{P}$ fertilization. Duncan's post hoc test $(P=0.05)$ also revealed that axis 1 scores significantly increased with fertilization at the 800-m elevation for the heath only. Meanwhile, axis 2 scores were significantly influenced by the interactive effect of $\mathrm{N} \times$ vegetation type $(F=7.9$, df $=1,72, P=0.010)$, because $\mathrm{N}$ fertilization tended to decrease axis 2 scores for the meadow but not for the heath. Axis 2 scores were also responsive to the effect of elevation (Appendix D) and the vegetation type $\times$ elevation interaction $(F=15.4$, df $=2,27, P<0.001)$. Duncan's post hoc test at $P=0.05$ revealed that this was because all elevations differed significantly from each other for the heath, and the 500$\mathrm{m}$ elevation differed significantly from the $800-\mathrm{m}$ and $1000-\mathrm{m}$ for the meadow.

\section{Discussion}

Responses to fertilization across contrasting elevations and vegetation types

Nutrient limitation often increases with increasing elevation and associated declines in temperature (Sveinbjörnsson 1995, Kitayama et al. 1998, Johnson et al. 2000), but some recent observational studies suggest that the relative importance of different limiting nutrients changes with elevation (van de Weg et al. 2009, Fisher et al. 2013). In addition, plant and soil microbial community composition can be closely associated (Bardgett and Wardle 2010, Eisenhauer et al. 2010), and vegetation responses to elevation can thus influence microbial responses (Löffler et al. 2008, Sundqvist et al. 2011a). Previous work in our study system has shown increasing limitation of plants by $\mathrm{P}$ relative to $\mathrm{N}$ with increasing elevation (Sundqvist et al. 2011b), and we therefore predicted that community properties at low and high elevations would be more responsive to $\mathrm{N}$ and $\mathrm{P}$ addition, respectively. However, we did not find this for either plant or microbial communities, leaving our first hypothesis unsupported. While no comparable fertilization study has been performed across contrasting elevational gradients in tundra, our findings are also inconsistent with a recent fertilization study in Peru, which revealed declining foliar N:P ratios and increasing responsiveness of plant growth to $\mathrm{N}$ addition as elevation increased from lowland tropical forest to montane cloud forest (Fisher et al. 2013). However, we found that different plant functional groups showed contrasting responses to fertilization, and to the interactive effects of fertilization with elevation and vegetation type. These varying responses of different floristic components are likely to have contributed to preventing community-level properties, such as total cover, species richness, and Shannon's diversity, from

V. uli $=$ Vaccinium uliginosum, $V$. vit $=$ Vaccinium vitis-idaea $. \mathrm{C}=$ total soil carbon, $\mathrm{N}=$ total soil nitrogen, $\mathrm{P}=$ total soil phosphorous, Moisture = soil moisture content, $\mathrm{AM}=$ arbuscular mycorrhizae, $\mathrm{F}: \mathrm{B}$ ratio = fungal-to-bacterial ratio. The biplot displays $37.1 \%$ of the variance explained by soil properties. The sum of all canonical eigenvalues is 2.122 . 


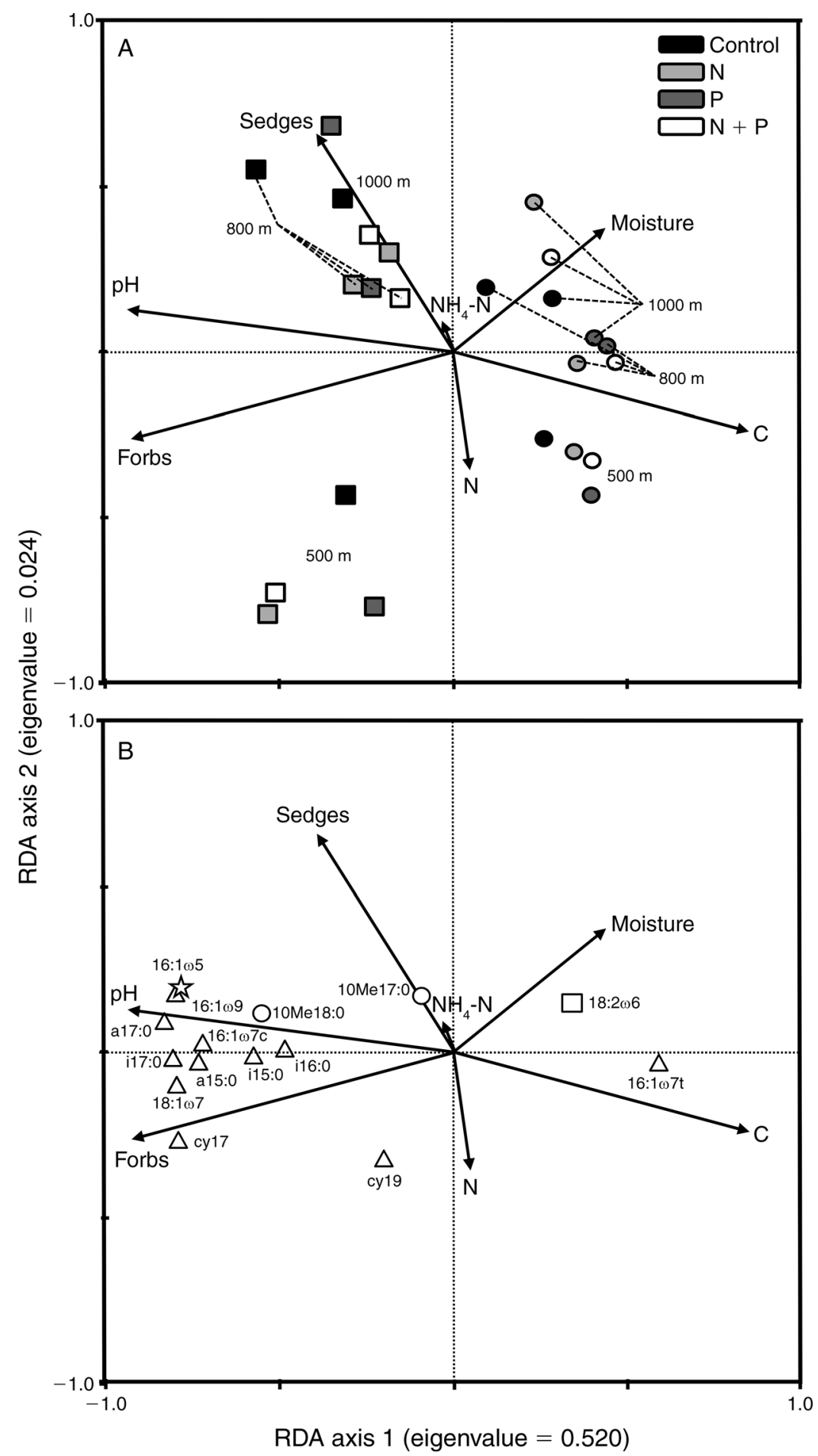

FIG. 6. Partial RDA of soil microbial community composition constrained by plant species and abiotic soil properties. (A) Biplot displaying means of the axis scores for each fertilizer treatment at each elevation within each vegetation type, and environmental (i.e., plant and abiotic soil) variables. Square symbols are meadow plots and circles are heath plots. Whenever Duncan's post hoc test at $P=0.05$ revealed significant differences among elevations, and among plots within elevations and vegetation types, these are presented in the results text. (B) Biplot of microbial phospholipid fatty acids and environmental (i.e., plant and abiotic soil) variables. The sum of all canonical eigenvalues is 0.571 and the biplot displays $57.1 \%$ of the variance explained by plant and soil properties. The relative amount of variance explained by plant and soil properties is $2.2 \%$ and $7.9 \%$, respectively, with a shared variance of $47.0 \%$. For the PLFAs, triangles $=$ bacteria, the square $=$ fungi, the star $=$ arbuscular mycorrhizal fungi and circles $=$ actinomycetes. 
showing simplistic responses to fertilization across the gradient. These findings are at least partly consistent with experimental manipulation studies in tundra systems spanning between 5 and 21 years that have shown complex interactions of fertilization and plant removal among coexisting plant functional groups (Bret-Harte et al. 2008, Suding et al. 2008, Wardle et al. 2013). Similarly, fertilization influenced the soil microbial community, but not in any consistent way across the gradient, which may be explained by different components of the microflora showing contrasting responses to fertilization and elevation.

We further predicted a greater effect of $\mathrm{P}$ fertilization on plant and microbial properties in meadow vegetation than in heath, and a greater effect of $\mathrm{N}$ fertilization in heath compared to meadow. Although soil nutrient concentrations in the unfertilized plots suggested higher soil $\mathrm{N}$ and lower soil $\mathrm{P}$ availability in the meadow than the heath (Fig. 4; Sundqvist et al. 2011a, Giesler et al. 2012), we found little support for our second hypothesis. Instead, most plant and microbial variables that we measured were only weakly responsive, or unresponsive, to the interactive effect of either $\mathrm{N}$ or $\mathrm{P}$ addition with vegetation type, meaning that heath and meadow did not differ much in their responsiveness to either fertilizer. However, vegetation density consistently showed a strong positive response to simultaneous $\mathrm{N}$ and $\mathrm{P}$ addition for both heath and meadow. This result after two years of fertilization is consistent with other experiments that have been conducted, over both the same (Madan et al. 2007) and longer (4-9 years) time spans (Shaver et al. 1998, Gough and Hobbie 2003, Zamin and Grogan 2012), in showing tundra vegetation to be most responsive to the combined effect of $\mathrm{N}$ and $\mathrm{P}$. This means that $\mathrm{N}$ and $\mathrm{P}$ can often co-limit tundra plants across contrasting vegetation types (Onipchenko et al. 2012).

Overall, $\mathrm{N}$ and $\mathrm{P}$ addition also had an overall positive effect on the fungal to bacterial ratios for both vegetation types, although this was statistically significant for only two elevations in the meadow. While the method used here (PLFA analysis) may not detect all potential changes in the microbial community, our results point to $\mathrm{N}$ and $\mathrm{P}$ fertilization favoring soil fungi over bacteria in at least some of our plots. In these cases, they therefore suggest that alleviation of $\mathrm{N}$ and $\mathrm{P}$ addition could be associated with a change in the competitive strength among major functional groups of soil microbes (Fierer et al. 2007). Since fungal-based food webs can be associated with a more conservative nutrient cycling in comparison to bacterial-based food webs, this observed change could potentially also influence nutrient turnover rates (Wardle et al. 2004), although this response requires further study. While our results may also be indicative of at least some plant and microbial properties being co-limited by $\mathrm{N}$ and $\mathrm{P}$ in our study system, they provide little evidence that the extent of this co-limitation differs strongly among vegetation types.

\section{Interactive effects of fertilization, elevation, and vegetation type}

In previous work on this system, concentrations of available soil nutrients declined with elevation for the heath but showed idiosyncratic responses for the meadow (Sundqvist et al. 2011a); we therefore predicted that plant and microbial variables would be most responsive to fertilization at higher elevations for the heath. A three-way interactive effect of fertilization, elevation, and vegetation type is needed for this hypothesis to hold. However, with regard to the plant community, we only found such an interactive effect for some variables, and never in a direction consistent with our third hypothesis. Instead, fertilization sometimes had greater effects on plant properties at the higher (and colder) elevations for the meadow, but at lower (and warmer) elevations for the heath (Figs. 1 and 2); this was especially apparent for the positive fertilization effects on vegetation density and graminoids, and negative effects on dwarf shrub cover. These results emphasize that the role of temperature in controlling tundra plant community responses to improved nutrient availability varies among vegetation types. As such, they suggest that with increasing temperature, $\mathrm{N}$ and $\mathrm{P}$ become less limiting factors for plants, dominating more fertile tundra soils, but more limiting for plants dominating poorer soils. Our results for the meadow are consistent with several studies in other ecosystems suggesting that increasing elevation (and thus declining temperature) is associated with reduced soil fertility and thus increased nutrient limitation (Vitousek et al. 1988, 1994, Sveinbjörnsson et al. 1995, Johnson et al. 2000). In contrast, for the heath, our results indicate that low temperatures constrain plant responses to improved nutrient availability at high elevations, consistent with work showing high-elevation tundra communities dominated by slowgrowing dwarf shrubs to be relatively resistant to fertilization (Haugwitz and Michelsen 2011). This highlights how opposing patterns of plant nutrient limitation can occur even across the same elevational gradient when different vegetation types are considered.

We also often found differences among heath and meadow vegetation in terms of how fertilizer effects on soil microbial properties changed with elevation, but again not in the direction predicted by our third hypothesis. However, most microbial variables were responsive to the interactive effects of fertilization with elevation and/or vegetation type, which highlights the importance of environmental context in determining when and how microbial communities respond to increased supply of $\mathrm{N}$ and $\mathrm{P}$ in the tundra landscape. Our data also showed that $\mathrm{N}+\mathrm{P}$ addition caused an increase in the ratio of fungal to bacterial biomass at the mid- and high elevation for the meadow. This is inconsistent with predictions that greater nutrient 
availability supports a more bacterial-based energy channel (Coleman et al. 1983, Bardgett and Wardle 2010), and with the results of some previous fertilizer experiments in tundra (Schmidt et al. 2000, Wardle et al. 2013). However, fungal-to-bacterial ratios were also least at the lowest (and thus warmest) elevation for both vegetation types (Fig. 3). Therefore, our results from two years of fertilization corroborate findings from a long-term (10-year) climate change experiment in subarctic tundra heath showing a positive effect of fertilization (NPK), but not warming, on fungal-tobacterial ratios (Rinnan et al. 2007). As such, the effect of alleviation of nutrient limitation by fertilization on soil microbial properties may not necessarily mirror the effect of long-term changes in temperature on microbes through influencing soil nutrient availability (Rinnan et al. 2007). Our results also at least partly contrast with those from an 18-year warming experiment in the Alaskan arctic suggesting that increasing dwarf shrub (Betula nana) growth in response to warming has an important role in enhancing soil fungal biomass (Deslippe et al. 2012). Taken together, our findings instead suggest that future warmer temperatures may be associated with an increased role of the bacterial-based energy channel in tundra soils regardless of nutrient availability or vegetation type.

\section{Decoupled responses of plants and microbes to fertilization}

Changes in both plant and soil abiotic properties along elevational gradients are known to influence soil microbial community responses to elevation (Sundqvist et al. 2011a, Wagai et al. 2011, Bahram et al. 2012), and our data is consistent with this (Fig. 6). Further, while addition of $\mathrm{N}$ and $\mathrm{P}$ to our plots always raised available levels of $\mathrm{N}$ and $\mathrm{P}$ in soil at specific elevations, they also influenced other properties that could potentially impact soil microbial communities, such as plant community composition (Grayston et al. 1998, Orwin et al. 2010) and soil pH (Lauber et al. 2009, Rousk et al. 2010). However, we found little evidence that plant community changes mediated the response of the microbial community composition to fertilization across contrasting elevations in the manner recently shown for the response of aboveground consumers (de Sassi et al. 2012). This was because those plant and soil abiotic properties that were most strongly altered by fertilization did not have any great impact on microbial community composition (Fig. 6). As such, within elevations microbial community composition changed significantly in response to fertilization only at $800 \mathrm{~m}$ for the heath (as revealed by Duncan's post hoc test at $P=0.05$; see Results), but this did not occur in association with any plant or abiotic soil variable that was responsive to fertilization (Fig. 6A). Generally, our results are broadly in agreement with experimental evidence from studies spanning 5-11 years that have shown that the dominant effects of fertilization on soil microbial communities operate directly (Marshall et al. 2011, Wardle et al. 2013) rather than indirectly via shifts in vegetation composition and thereby plant-soil feedbacks (Suding et al. 2008). They further highlight how these direct effects can differ greatly among communities, and depend on factors such as type of nutrient addition (i.e., $\mathrm{N}$ and/or $\mathrm{P}$ ), elevation, and vegetation type.

\section{Conclusions}

Our results show that plant and microbial properties in tundra can be responsive to elevation and fertilization as well as their interaction, but that these responses can vary among vegetation types, and with plant and soil microbial communities sometimes responding in markedly different ways. These results have several implications. First, they show that the response to nutrient addition and increasing elevation for both plant and microbial communities is not constant among differing vegetation types. Instead, we found that significant plant responses to $\mathrm{N}$ and $\mathrm{P}$ added in combination (i.e., Shannon's diversity and vegetation density) were greatest at lower elevations for heath, but at higher elevations for meadow vegetation, and that while microbial responses to these nutrients were weaker, these also differed among vegetation types and elevations. Second, they suggest that plant community responses to nutrient addition may not necessarily be an important determinant of microbial community responses, irrespective of elevation or vegetation type, indicative of a decoupled response of plant and microbial communities to changes in temperature and soil fertility. These results further suggest that the relative importance of temperature vs. nutrient limitation differs for tundra plant and microbial communities across tundra landscapes. However, we stress that further work is needed to understand the mechanistic basis for these decoupled responses. Since our results are also broadly in line with more long-term manipulations of plant functional groups and nutrients in tundra (Wardle et al. 2013), plant community responses to climate change may be poor predictors of microbial community responses in these ecosystems. Finally, they highlight how manipulating soil fertility for contrasting vegetation types across an elevational gradient may help us better understand the mechanistic basis through which changes in temperature influence plant and soil communities, and the linkages between them, at the landscape scale (Sundqvist et al. 2013). Since elevational gradients allow us to determine how communities and ecosystems respond to changes in temperature that are of similar magnitude to those expected to occur through global climate change (Fukami and Wardle 2005, Malhi et al. 2010, Sundqvist et al. 2013), this type of information is essential for predicting tundra responses to climate change across vegetation types and levels of soil fertility (Wookey et al. 2009). 


\section{ACKNOWLedgments}

The authors thank Anna Berg, Paul Kardol, and Thomas Westin for field help, Helena Gustafsson, Kelley Gundale, and the staff at the Abisko Scientific Research Station and Climate Impacts Research Centre for laboratory help, and Daniel B. Metcalfe and two anonymous reviewers for helpful comments on an earlier version of the manuscript. This study was supported by the Centre for Environmental Research in Umeå (CMF), by the Swedish Research Council (VR) to R. Giesler, and by a Wallenberg Scholars award to D. A. Wardle. M. K. Sundqvist and Z. Liu contributed equally to this article.

\section{Literature Cited}

ACIA. 2005. Arctic climate impact assessment (ACIA). Cambridge University Press, Cambridge, UK.

Aerts, R., and F. S. Chapin III. 2000. The mineral nutrition of wild plants revisited: a re-evaluation of processes and patterns. Pages 1-67 in A. H. Fitter and D. G. Raffaelli, editors. Advances in Ecological Research 30. Academic Press, San Diego, California, USA.

Bahram, M., S. Põlme, U. Kõljalg, S. Zarre, and L. Tedersoo. 2012. Regional and local patterns of ectomycorrhizal fungal diversity and community structure along an altitudinal gradient in the Hyrcanian forests of northern Iran. New Phytologist 193:465-473.

Bardgett, R. D., and D. A. Wardle. 2010. Abovegroundbelowground linkages: biotic interactions, ecosystem processes and global change. Oxford University Press, Oxford, UK.

Björk, R. G., L. Klemedtsson, U. Molau, J. Harndorf, A. Ödman, and R. Giesler. 2007. Linkages between N turnover and plant community structure in a tundra landscape. Plant and Soil 294:247-261.

Borcard, D., P. Legendre, and P. Drapeau. 1992. Partialling out the spatial component of ecological variation. Ecology 73: 1045-1055.

Bret-Harte, M. S., M. C. Mack, G. R. Goldsmith, D. B. Sloan, J. De Marco, G. R. Shaver, P. M. Ray, Z. Biesinger, and F. S. Chapin III. 2008. Plant functional types do not predict biomass responses to removal and fertilization in Alaskan tussock tundra. Journal of Ecology 96:713-726.

Chapin, F. S., III, and G. R. Shaver. 1985. Individualistic growth response of tundra plant species to environmental manipulations in the field. Ecology 66:564-576.

Chapin, F. S., III, G. R. Shaver, A. E. Giblin, K. J. Nadelhoffer, and J. A. Laundre. 1995. Responses of arctic tundra to experimental and observed changes in climate. Ecology 76:694-711.

Coleman, D. C., C. P. P. Reid, and R. V. Cole. 1983. Biological strategies of nutrient cycling in soil systems. Pages 1-51 in A. MacFayden and E. O. Ford, editors. Advances in Ecological Research 13. Academic Press, New York, New York, USA.

Craine, J. M., C. Morrow, and N. Fierer. 2007. Microbial nitrogen limitation increases decomposition. Ecology 88: 2105-2113.

de Sassi, C., O. T. Lewis, and J. M. Tylianakis. 2012. Plantmediated and nonadditive effects of two global change drivers on an insect herbivore community. Ecology 93:18921901.

Deslippe, J. R., M. Hartmann, S. W. Simard, and W. W. Mohn. 2012. Long-term warming alters the composition of Arctic soil microbial communities. FEMS Microbiology Ecology 82:303-315.

Eisenhauer, N., et al. 2010. Plant diversity effects on soil microorganisms support the singular hypothesis. Ecology 91: 485-496.

Eskelinen, A., S. Stark, and M. Männistö. 2009. Links between plant community composition, soil organic matter quality and microbial communities in contrasting tundra habitats. Oecologia 161:113-123.
Fierer, N., M. A. Bradford, and R. B. Jackson. 2007. Toward an ecological classification of soil biota. Ecology 88:13541364.

Fisher, J. B., Y. Malhi, I. Cuba Torres, D. B. Metcalfe, M. J. van de Weg, P. Meir, J. E. Silva-Espejo, and W. Huaraca Huasco. 2013. Nutrient limitation in rainforests and cloud forests along a 3,000-m elevation gradient in the Peruvian Andes. Oecologia 172:889-902.

Frostegård, A., and E. Bååth. 1996. The use of phospholipid analysis to estimate bacterial and fungal biomass in soil. Biology and Fertility of Soils 22:59-65.

Frostegård, Å., A. Tunlid, and E. Bååth. 1991. Microbial biomass measured as total lipid phosphate in soils of different organic content. Journal of Microbiological Methods 14: 239-245.

Fukami, T., and D. A. Wardle. 2005. Long-term ecological dynamics: reciprocal insights from natural and anthropogenic gradients. Proceedings of the Royal Society B 272:21052115.

Giesler, R., C. Esberg, A. Lagerström, and B. J. Graae. 2012. Phosphorus availability and microbial respiration across different tundra vegetation types. Biogeochemistry 108:429445 .

Goodall, D. W. 1952. Some considerations in the use of point quadrats for the analysis of vegetation. Australian Journal of Scientific Research Series B-Biological Sciences 5:1-41.

Gough, L., and S. E. Hobbie. 2003. Responses of moist nonacidic arctic tundra to altered environment: productivity, biomass, and species richness. Oikos 103:204-216.

Gough, L., C. W. Osenberg, K. L. Gross, and S. L. Collins. 2000. Fertilization effects on species density and primary productivity in herbaceous plant communities. Oikos 89: 428-439.

Grayston, S. J., S. Wang, C. D. Campbell, and A. C. Edwards. 1998. Selective influence of plant species on microbial diversity in the rhizosphere. Soil Biology and Biochemistry 30:369-378.

Haugwitz, M. S., and A. Michelsen. 2011. Long-term addition of fertilizer, labile carbon, and fungicide alters the biomass of plant functional groups in a subarctic-alpine community. Plant Ecology 212:715-726.

Hoch, G., and C. Körner. 2012. Global patterns of mobile carbon stores in trees at the high-elevation tree line. Global Ecology and Biogeography 21:861-871.

Hodkinson, I. D. 2005. Terrestrial insects along elevation gradients: species and community responses to altitude. Biological Reviews 80:489-513.

IBM SPSS. 2011. IBM SPSS v20. IBM SPSS, Chicago, Illinois, USA.

IPCC. 2007. Climate Change 2007: synthesis report. In R. K. Pachauri and A. Reisinger, editors. Contribution of Working Groups I, II and III to the Fourth Assessment Report of the Intergovernmental Panel on Climate Change. Cambridge University Press, Cambridge, UK.

Johnson, C. E., C. T. Driscoll, T. G. Siccama, and G. E. Likens. 2000. Element fluxes and landscape position in a northern hardwood forest watershed ecosystem. Ecosystems 3:159184.

Jonasson, S. 1992. Plant responses to fertilization and species removal in tundra related to community structure and clonality. Oikos 63:420-429.

Karlsson, J., A. Jonsson, and M. Jansson. 2005. Productivity of high-latitude lakes: climate effect inferred from altitude gradient. Global Change Biology 11:710-715.

Kitayama, K., S.-I. Aiba, N. Majalap-Lee, and M. Ohsawa. 1998. Soil nitrogen mineralization rates of rainforests in a matrix of elevations and geological substrates on Mount Kinabalu, Borneo. Ecological Research 13:301-312.

Kohler, J., O. Brandt, M. Johannson, and T. Callaghan. 2006. A long-term Arctic snow depth record from Abisko, northern Sweden, 1913-2004. Polar Research 25:91-113. 
Körner, C. 2007. The use of 'altitude' in ecological research. Trends in Ecology and Evolution 22:569-574.

Kroppenstedt, R. M. 1985. Fatty acid menaquinone analysis of actinomycetes and related organisms. Pages 173-199 in M. Goodfellow and D. E. Minnikin, editors. Chemical methods in bacterial systematics. Academic Press, San Diego, California, USA.

Lauber, C., M. Hamady, R. Knight, and N. Fierer. 2009. Pyrosequencing-based assessment of soil $\mathrm{pH}$ as a predictor of soil bacterial community structure at the continental scale. Applied and Environmental Microbiology 75:5111-5120.

Lechevalier, M. P. 1977. Lipids in bacterial taxonomy-a taxonomists view. Critical Reviews in Microbiology 5:109210.

Liu, L., P. Gundersen, T. Zhang, and J. Mo. 2012. Effects of phosphorus addition on soil microbial biomass and community composition in three forest types in tropical China. Soil Biology and Biogeochemistry 44:31-38.

Löffler, U. C. M., H. Cypionka, and J. Löffler. 2008. Soil microbial activity along an arctic-alpine altitudinal gradient from a seasonal perspective. European Journal of Soil Science 59:842-854.

Mack, M. C., E. A. G. Schuur, M. S. Bret-Harte, G. R. Shaver, and F. S. Chapin III. 2004. Ecosystem carbon storage in arctic tundra reduced by long-term nutrient fertilization. Nature 431:440-443.

Madan, N. J., L. J. Deacon, and C. H. Robinson. 2007. Greater nitrogen and/or phosphorus availability increase plant species' cover and diversity at a High Arctic polar semidesert. Polar Biology 30:559-570.

Malhi, Y., M. Silman, N. Salinas, M. Bush, P. Meir, and S. Saatchi. 2010. Introduction: elevation gradients in the tropics: laboratories for ecosystem ecology and global change research. Global Change Biology 16:3171-3175.

Margesin, R., M. Jud, D. Tscherko, and F. Schinner. 2008. Microbial communities and activities in alpine and subalpine soils. FEMS Microbiology Ecology 67:208-218.

Marshall, C. B., J. R. McLaren, and R. Turkington. 2011. Soil microbial communities resistant to changes in plant functional group composition. Soil Biology and Biochemistry 43: 78-85.

Milbau, A., A. Shevtsova, N. Osler, M. Mooshammer, and B. J. Graae. 2013. Plant community type and small-scale disturbances, but not altitude, influence the invasability in subarctic ecosystems. New Phytologist 197:1002-1011.

Olsson, P. A. 1999. Signature fatty acids provide tools for determination of the distribution and interactions of mycorrhizal fungi in soil. FEMS Microbiology Ecology 29:303-310.

Onipchenko, V. G., M. I. Makarov, A. A. Akhmetzhanova, N. A. Soudzilovskaia, F. U. Aibazova, M. K. Elkanova, A. V. Stogova, and J. H. C. Cornelissen. 2012. Alpine plant functional group responses to fertilizer addition depend on abiotic regime and community composition. Plant and Soil 357:103-115.

Orwin, K. H., S. M. Buckland, D. Johnson, B. L. Turner, S. Smart, S. Oakley, and R. D. Bardgett. 2010. Linkages of plant traits to soil properties and the functioning of temperate grassland. Journal of Ecology 98:1074-1083.

Ramirez, K. S., C. L. Lauber, R. Knight, M. A. Bradford, and N. Fierer. 2010. Consistent effects of nitrogen fertilization on soil bacterial communities in contrasting systems. Ecology 91:3463-3470.

Rinnan, R., A. Michelsen, and E. Bååth. 2013. Fungi benefit from two decades of increased nutrient availability in tundra heath soil. PLoS ONE 8(2):e56532.

Rinnan, R., A. Michelsen, E. Bååth, and S. Jonasson. 2007. Fifteen years of climate change manipulations alter soil microbial communities in a subarctic heath ecosystem. Global Change Biology 13:28-39.

Rousk, J., E. Bååth, P. C. Brookes, C. L. Lauber, C. Lozupone, G. Caporaso, R. Knight, and N. Fierer. 2010. Soil bacterial and fungal communities across a $\mathrm{pH}$ gradient in an arable soil. ISME Journal 4:1340-1351.

Schinner, F. 1982. Soil microbial activities and litter decomposition related to altitude. Plant and Soil 65:87-94.

Schmidt, I. K., L. Ruess, E. Bååth, A. Michelsen, F. Ekelund, and S. Jonasson. 2000. Long-term manipulation of the microbes and microfauna of two subarctic heaths by addition of fungicide, bactericide, carbon and fertilizer. Soil Biology and Biochemistry 32:707-720.

Seastedt, T. R., and L. Vaccaro. 2001. Plant species richness, productivity, and nitrogen and phosphorus limitations across a snowpack gradient in alpine tundra, Colorado, USA. Arctic, Antarctic, and Alpine Research 33:100-106.

Shaver, G. R., L. C. Johnson, D. H. Cades, G. Murray, J. A. Laundre, E. B. Rastetter, K. J. Nadelhoffer, and A. E. Giblin. 1998. Biomass and $\mathrm{CO}_{2}$ flux in wet sedge tundras: responses to nutrients, temperature, and light. Ecological Monographs 68:75-97.

Suding, K. N., I. W. Ashton, H. Bechtold, W. D. Bowman, M. L. Mobley, and R. Winkleman. 2008. Plant and microbe contribution to community resilience in a directionally changing environment. Ecological Monographs 78:313-329.

Sundqvist, M. K. 2011. Nitrogen and phosphorus dynamics across an elevational gradient in a Swedish subarctic tundra. Dissertation. Faculty of Forest Sciences, Swedish University of Agricultural Sciences (SLU), Umeå, Sweden.

Sundqvist, M. K., R. Giesler, B. J. Graae, H. Wallander, E. Fogelberg, and D. A. Wardle. 2011a. Interactive effects of vegetation type and elevation on aboveground and belowground properties in a subarctic tundra. Oikos 120:128-142.

Sundqvist, M. K., R. Giesler, and D. A. Wardle. 2011b. Withinand across-species responses of plant traits and litter decomposition to elevation across contrasting vegetation types in subarctic tundra. PLoS ONE 6(10):e27056.

Sundqvist, M. K., N. J. Sanders, and D. A. Wardle. 2013. Community and ecosystem responses to elevational gradients: processes, mechanisms and insights for global change. Annual Review of Ecology, Evolution, and Systematics 44: 261-280.

Sundqvist, M. K., D. A. Wardle, E. Olofsson, R. Giesler, and M. J. Gundale. 2012. Chemical properties of plant litter in response to elevation: subarctic vegetation challenges phenolic allocation theories. Functional Ecology 26:1090-1099.

Sveinbjörnsson, B., J. Davis, W. Abadie, and A. Butler. 1995. Soil carbon and nitrogen mineralization in the Chugach Mountains of South-Central Alaska, USA. Arctic and Alpine Research 27:29-37.

Tamm, C. O. 1991. Nitrogen in terrestrial ecosystems: questions of productivity, vegetational changes, and ecosystem stability. In W. D. Billings, F. Colley, O. L. Lange, J. S. Olson, and H. Rammert, editors. Ecological Studies, Volume 81. Springer-Verlag, New York, New York, USA.

ter Braak, C. J. F., and P. Šmilauer. 2002. CANOCO reference manual and CanoDraw for Windows user's guide: software for canonical community ordination (ver. 4.5). Microcomputer Power, Ithaca, New York, USA.

Thompson, M., and S. J. Wood. 1982. Atomic absorption methods in applied geochemistry. Pages 261-284 in J. E. Cantle, editor. Atomic absorption spectrometry. Elsevier, Amsterdam, The Netherlands.

van de Weg, M., P. Meir, J. Grace, and O. K. Atkin. 2009. Altitudinal variation in leaf mass per unit area, leaf tissue density and foliar nitrogen and phosphorus content along an Amazon-Andes gradient in Peru. Plant Ecology and Diversity $2: 243-254$.

Vitousek, P. M. 2004. Nutrient cycling and limitation: Hawai`i as a model system. Princeton University Press, Princeton, New Jersey, USA.

Vitousek, P. M., P. A. Matson, and D. R. Turner. 1988. Elevational and age gradients in Hawaiian montane rainforest: foliar and soil nutrients. Oecologia 77:565-570. 
Vitousek, P. M., D. R. Turner, W. J. Parton, and R. L. Sanford. 1994. Litter decomposition on the Mauna Loa environmental matrix, Hawai'i: patterns, mechanisms, and models. Ecology 75:418-429.

Wagai, R., K. Kitayama, T. Satomura, R. Fujinuma, and T. Balser. 2011. Interactive influences of climate and parent material on soil microbial community structure in Bornean tropical forest ecosystems. Ecological Research 26:627-636.

Wardle, D. A. 2002. Communities and ecosystems: linking the aboveground and belowground components. Princeton University Press, Princeton, New Jersey, USA.

Wardle, D. A., R. D. Bardgett, J. N. Klironomos, H. Setälä, W. H. van der Putten, and D. Wall. 2004. Ecological linkages between above and belowground biota. Science 304:16291633.

Wardle, D. A., M. J. Gundale, A. Jäderlund, and M.-C. Nilsson. 2013. Decoupled long term effects of nutrient enrichment on aboveground and belowground properties in subalpine tundra. Ecology 94:904-919.
Wardle, D. A., G. Hörnberg, O. Zackrisson, M. KalelaBrundin, and D. A. Coomes. 2003. Long term effects of wildfire on ecosystem properties across an island area gradient. Science 300:972-975.

Weintraub, M. N. 2011. Biological phosphorus cycling in arctic and alpine soils. Pages 295-316 in E. K. Bünemann, A. Oberson, and E. Frossard, editors. Phosphorus in action. Soil Biology 26. Springer-Verlag, Berlin, Germany.

Whittaker, R. H. 1956. Vegetation of the Great Smokey Mountains. Ecological Monographs 26:1-80.

Wookey, P. A., et al. 2009. Ecosystem feedbacks and cascade processes: understanding their role in the responses of arctic and alpine ecosystems to environmental change. Global Change Biology 15:1153-1172.

Zamin, T. J., and P. Grogan. 2012. Birch shrub growth in the low Arctic: the relative importance of experimental warming, enhanced nutrient availability, snow depth and caribou exclusion. Environmental Research Letters 7:034027.

\section{Supplemental Material}

Appendix A

Daily summer mean temperature across the study site (Ecological Archives E095-161-A1).

\section{Appendix B}

ANOVA results testing for effects of $\mathrm{N}$ and $\mathrm{P}$ fertilization, vegetation type, elevation, and their interactions on vegetation properties (Ecological Archives E095-161-A2).

\section{Appendix C}

Plant functional group cover in control and fertilizer plots across the study site (Ecological Archives E095-161-A3).

\section{Appendix D}

ANOVA results testing for effects of $\mathrm{N}$ and $\mathrm{P}$ fertilization, vegetation type, elevation, and their interactions on soil microbial properties (Ecological Archives E095-161-A4).

\section{Appendix E}

ANOVA results testing for the effects of $\mathrm{N}$ and $\mathrm{P}$ fertilization, vegetation type, elevation, and their interactions on soil abiotic properties (Ecological Archives E095-161-A5).

\section{Appendix F}

Soil abiotic properties (means \pm standard errors) in control and fertilizer plots across the study site (Ecological Archives E095-161-A6). 